\title{
Selenium-containing enzymes in mammals: Chemical perspectives
}

\author{
GOURIPRASANNA ROY, BANI KANTA SARMA, PRASAD P PHADNIS and G MUGESH* \\ Department of Inorganic and Physical Chemistry, Indian Institute of Science, Bangalore 560 012, India \\ e-mail: mugesh@ipc.iisc.ernet.in
}

MS received 22 March 2005; accepted 6 June 2005

\begin{abstract}
The chemical and biochemical route to the synthesis of the 21 st amino acid in living systems, selenocysteine, is described. The incorporation of this rare amino acid residue into proteins is described with emphasis on the role of monoselenophosphate as selenium source. The role of selenocysteine moiety in natural mammalian enzymes such as glutathione peroxidase (GPx), iodothyronine deiodinase (ID) and thioredoxin reductase (TrxR) is highlighted and the effect of other amino acid residues located in close proximity to selenocysteine is described. It is evident from various studies that two amino acid residues, tryptophan and glutamine, appear in identical positions in all known members of the GPx family. According to the three-dimensional structure established for bovine GPx, these residues could constitute a catalytic triad in which the selenol group of the selenocysteine is both stabilized and activated by hydrogen bonding with the imino group of the tryptophan (Trp) residue and with the amido group of the glutamine (Gln) residue. The ID enzymes, on the other hand, do not possess any Trp or Gln residues in close proximity to selenium, but contain several histidine residues, which may play important roles in the catalysis. The TrxR enzymes also possess some basic histidines, but the most important amino acid residues are the cysteines which constitute the internal cofactor systems along with the catalytically active selenocysteine. The catalytic activity and substrate specificity of all three selenoenzymes are described. The reactivity of selenocysteine residues in selenoenzymes towards metal-based drugs such as goldthioglucose is also described.
\end{abstract}

Keywords. Antioxidants; cysteine; deiodination; monoselenophosphate; selenium selenocysteine, selenoenzymes, thyroxine.

\section{Introduction}

Selenium was discovered in 1818 by the Swedish chemist Berzelius and was named after the Greek moon goddess, Selene. ${ }^{1}$ This main group element belongs to group 16 of the periodic table and in nature it is associated with sulphur in a ratio between $1: 10^{3}$ and $1: 10^{5}$. In biology, selenium, in contrast to sulphur, was long considered a poison until Schwarz and Foltz identified it as a micronutrient for bacteria, mammals, and birds. ${ }^{2}$ After 15 years of empirical studies on selenium-deficiency syndrome in experimental animals, selenium biochemistry came of age in 1973 when two bacterial enzymes, formate dehydrogenase ${ }^{3}$ and glycine reductase, ${ }^{4}$ were reported to contain selenium. At the same time, the biochemical role of selenium in mammals was clearly established by the discovery that it is part of the active site of the antioxidant enzyme glutathione peroxidase (GPx) ${ }^{5,6}$ The number of selenoproteins identified has grown substantially

*For correspondence in recent years (table 1) ${ }^{7,8}$ In prokaryotes, formate dehydrogenases, ${ }^{9}$ hydrogenases, ${ }^{10-12}$ and glycine reductase $^{13,14}$ are a few representative examples in which selenocysteine ${ }^{15,16}$ has been verified as the selenium moiety. In contrast, selenium is bound to a cysteine residue in $\mathrm{CO}$ dehydrogenase, where it forms a redox active centre with cofactor-bound molybdenum. ${ }^{17}$ In eukaryotes, iodothyronine deiodinases,${ }^{18-21}$ thioredoxin reductases, ${ }^{22-27}$ selenophosphate synthetase, ${ }^{26}$ and selenoprotein $\mathrm{P}^{28}$ represent important classes of selenoenzymes in addition to the well-known glutathione peroxidases. ${ }^{5,6,29-32}$ Many books and reviews available in the literature describe various biological functions of selenium, including nutritional importance ${ }^{33-38}$ The purpose of this article is to give an overview of the chemical aspects of selenocysteine in the active sites of mammalian selenoenzymes.

\section{Selenocysteine - The 21 st amino acid}

The major biological form of selenium is represented by the amino acid selenocysteine (Sec). The selenol 
Table 1. Selenocysteine-containing enzymes and their biological functions.

\begin{tabular}{ll}
\hline Enzyme & \multicolumn{1}{c}{ Reaction } \\
\hline Formate dehydrogenases & $\mathrm{HCOOH} \rightarrow \mathrm{CO}_{2}+2 \mathrm{H}^{+}+2 e^{-}$ \\
NiFeSe-hydrogenases & $\mathrm{H}_{2} \rightarrow 2 \mathrm{H}^{+}+2 e^{-}$ \\
Glycine reductase & $\mathrm{Gly}+2 e^{-}+4 \mathrm{H}^{+}+\mathrm{ADP}+\mathrm{P}_{\mathrm{i}} \rightarrow$ acetete $+\mathrm{NH}_{4}^{+}+\mathrm{ATP}$ \\
Selenophosphate synthatase & $\mathrm{HSe}^{-}+\mathrm{ATP} \rightarrow \mathrm{HSe}-\mathrm{PO}_{3} \mathrm{H}_{2}+\mathrm{AMP}+\mathrm{P}_{\mathrm{i}}$ \\
Glutathione peroxidases $(\mathrm{GPx})$ & $\mathrm{H}_{2} \mathrm{O}_{2}+2 \mathrm{GSH} \rightarrow \mathrm{H}_{2} \mathrm{O}+\mathrm{GSSG}$ \\
Phospholipid-hydroperoxide-GPx & $\mathrm{ROOH}+2 \mathrm{GSH} \rightarrow \mathrm{R}-\mathrm{OH}+\mathrm{H}_{2} \mathrm{O}+\mathrm{GSSG}$ \\
Type I iodothyronine deiodinase & L-Thyroxine $+2 e^{-}+\mathrm{H}^{+} \rightarrow 3,5,3^{\prime}$-triiodothyronine $+\mathrm{I}^{-}$ \\
Thioredoxin reductase & $\mathrm{NADPH}+\mathrm{Trx} \mathrm{ox} \rightarrow \mathrm{NADP}^{+}+\mathrm{Trx}_{\text {red }}$ \\
Selenoprotein W & $?$ \\
Selenoprotein P & Antioxidant? \\
\hline
\end{tabular}

GSH: reduced glutathione, ROOH: Lipid hydroperoxide, Trx: thioredoxin

group in the free amino acid (1) is unstable and readily oxidizes in air to the corresponding diselenide (2). However, the diselenide can be easily reduced by thiols such as dithiothreitol (DTT) under physiological conditions.<smiles>NC(C[SeH])C(=O)O</smiles>

Selenocysteine, 1<smiles>NC(C[Se][Se]CC(N)C(=O)O)C(=O)O</smiles>

Selenocystine, 2
The presence of a Sec residue in the active centre of an enzyme instead of a Cys confers a dramatic catalytic advantage. The lower $\mathrm{pKa}(5 \cdot 2)$ of the selenol group in the active site as compared with thiol (8.0) may account for this catalytic advantage. Therefore, the selenol group is fully dissociated at physiological $\mathrm{pH}$ and the dissociated selenolate in enzyme's active site is a much better nucleophile than the corresponding thiolate. These properties and the unique redox behaviour of selenium make the Sec residues more reactive than Cys and, therefore, the Sec residues in selenoenzymes can be termed as "superreactive cysteines". A comparison of purified variants of formate dehydrogenase containing either a cysteine or a selenocysteine in the active site revealed that the overall catalytic efficiency is more than 300 -fold higher for the selenium-containing variant. ${ }^{7}$ A drastic reduction of the activity was also found in genetically constructed variants of the type I deiodonase when they contained a cysteine residue in the position of the selenocysteine. ${ }^{39}$ In another case, replacement of the catalytically essential Cys residue in glyceraldehyde 3-phosphate dehydrogenase (GAPDH) with Sec converted the phosphate dehydrogenase into a peroxidase. $^{40}$
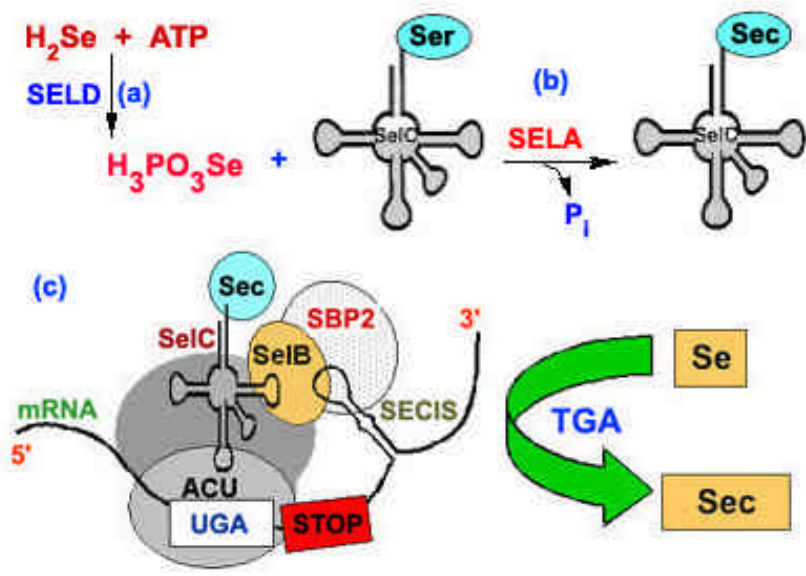

Scheme 1. Proposed model for Sec incorporation in Eukarya. (a) Synthesis of the selenium donor, monoselenophosphate; (b) conversion of seryl-tRNA ${ }^{\text {Sec }}$ to selenocysteyl-tRNA $^{\mathrm{Sec}}$; (c) formation of the complex for the cotranslational incorporation of Sec.

Interestingly, unlike other amino acids present in proteins, Sec is not coded for directly in the genetic code. Alternatively, Sec is encoded by a UGA codon, which is normally a stop codon but, in these exceptional proteins, is modified by a subsequent sequence in the mRNA molecule that encodes the enzyme. For specific Sec insertion at UGA codons, a unique selenocysteyl-tRNA ${ }^{\text {Sec }}$ is synthesized from seryl-tRNA ${ }^{\mathrm{Sec}}$ using selenophosphate as the reactive selenium donor compound. ${ }^{41}$ Decoding of the UGA codon as Sec and its subsequent incorporation, therefore, requires a complex multi-component system and several reactions (scheme 1). These include: (a) the formation of the selenium donor, selenophosphate, from ATP and selenide, catalysed by the selenophosphate synthetase-2 (SELD), which is a sele- 
noenzyme by itself; (b) a specific tRNA, called tRNA (Ser)Sec or SelC, which is first loaded with serine and then converted into $\mathrm{Sec}$ by selenocysteine synthase (SELA) using selenophosphate as selenium source; (c) a putative translation complex in analogy to the established complex in prokarya. The mRNA forms a characteristic secondary structure in the $3^{\prime}$ nontranslated region, the Sec incorporating sequence (SECIS). The Sec-loaded tRNA(Ser)Sec is transferred to the ribosome A site and recognizes the UGA codon by its anti-codon ACU. The complex is stabilized via the interaction of putative SECIS-binding proteins (SelB) with the SECIS and the tRNA. ${ }^{42}$

\subsection{Monoselenophosphate, the selenium donor molecule}

The selenium donor for the nucleophilic addition during Sec incorporation has been identified as monoselenophosphate. ${ }^{43}$ The mechanism of selenophosphate synthesis from ATP and selenide has been investigated in isotope-labelling experiments, and in various types of isotope exchange experiments. The multi-step process involves formation of a phosphorylated enzyme derivative and tightly bound ADP. Transfer of the enzyme phosphoryl group to selenium forms selenophosphate and hydrolysis of the bound ADP gives orthophosphate and AMP as below.

$$
\begin{aligned}
& \mathrm{ATP}+\mathrm{E} \rightarrow \mathrm{E}-\mathrm{P}[\mathrm{ADP}], \\
& \mathrm{E}-\mathrm{P}[\mathrm{ADP}]+\mathrm{SE}^{-} \rightarrow \mathrm{HSe}-\mathrm{PO}_{3} \mathrm{H}_{2}+\mathrm{E}+\mathrm{AMP}+\mathrm{Pi},
\end{aligned}
$$

$$
\mathrm{ATP}+\mathrm{HSe}^{-} \rightarrow \mathrm{HSe}-\mathrm{PO}_{3} \mathrm{H}_{2}+\mathrm{P}_{\mathrm{I}}+\mathrm{AMP} .
$$

Selenophosphate synthetase is a monomeric enzyme of $37 \mathrm{kDa}$. Analysis of the Escherichia coli enzyme suggests that a cysteine residue (Cys17) may be involved in the catalysis. ${ }^{16,44}$ It is intriguing that enzymes from many other organisms contain a Sec in this position. A mechanism must therefore exist to circumvent the 'chicken and egg' situation that the product of the reaction of an enzyme is required for its own synthesis. It must be noted that several other organisms also produce selenophosphate synthetase analogues, but these enzymes contain an Arg or Thr residue in position 17. One of such variants has been purified from Drosophila melanogaster; however, the protein has been found to be devoid of selenium-dependent selenophosphate synthetase activity. ${ }^{44}$
2.2 Conversion of seryl-tRNA ${ }^{\text {Sec }}$ to selenocysteyl$t R N A^{\text {Sec }}$

The monoselenophosphate synthesized by selenophosphate synthetase is used for the converstion of seryl-tRNASec into selenocysteyl-tRNASec by another enzyme called selenocysteine synthase encoded by the selA gene in E. coli. ${ }^{45}$ Although experimental evidence exists for such a reaction in various eukarya systems, the enzyme has yet to be identified. ${ }^{46}$ For various bacteria, selenocysteine synthase has been shown to be a homo-decamer with a molecular mass of about $500 \mathrm{kDa} .{ }^{47}$ The reaction proceeds by the covalent binding of seryltRNA ${ }^{\text {Sec }}$ to the pyridoxal phosphate of selenocysteine synthase, which to date is the only PLP enzyme to bind a nucleic acid. The elimination of a water molecule from the seryl moiety followed by reaction with monoselenophospate produces selenocysteyl-tRNA $^{\mathrm{Sec}}$ (scheme 2). ${ }^{48,49}$

\section{Synthetic methods to incorporate Sec into proteins}

\section{$3.1 \quad$ Native chemical ligation}

Synthetic introduction of Sec into peptides is an attractive alternative to recombinant methods due to the complications associated with decoding the UGA stop codon described in the introduction. A number of synthetic peptides and proteins have been prepared by solid phase peptide synthesis (SPPS) that incorporated selenocysteine by using Boc- or Fmoc-Sec (PMB)-OH. ${ }^{50}$ By using the native chemical ligation technique the ability to synthetically introduce a free selenol (or diselenide) into a peptide permits entry into larger peptides/proteins. In the selenocysteine version of native chemical ligation, two ligation partners, one a C-terminal peptide thioester and the other a peptide containing an unprotected $\mathrm{Sec} /$ selenocystine at its $\mathrm{N}$ terminus, are mixed together along with a reducing agent. After an initial trans selenoesterification, a selenoester $\mathbf{1}$ is formed (scheme 3). This intermediate rearranges through an Se-to-N acyl shift to give the thermodynamically stable native peptide bond. Several recent model studies have shown the feasibility of this process.

In order to achieve an effective native chemical ligation, suitably protected selenocysteine derivatives are required. Walter and co-workers reported one of the first syntheses of optically pure selenocysteine derivatives. ${ }^{51}$ A key step in the preparation involved 


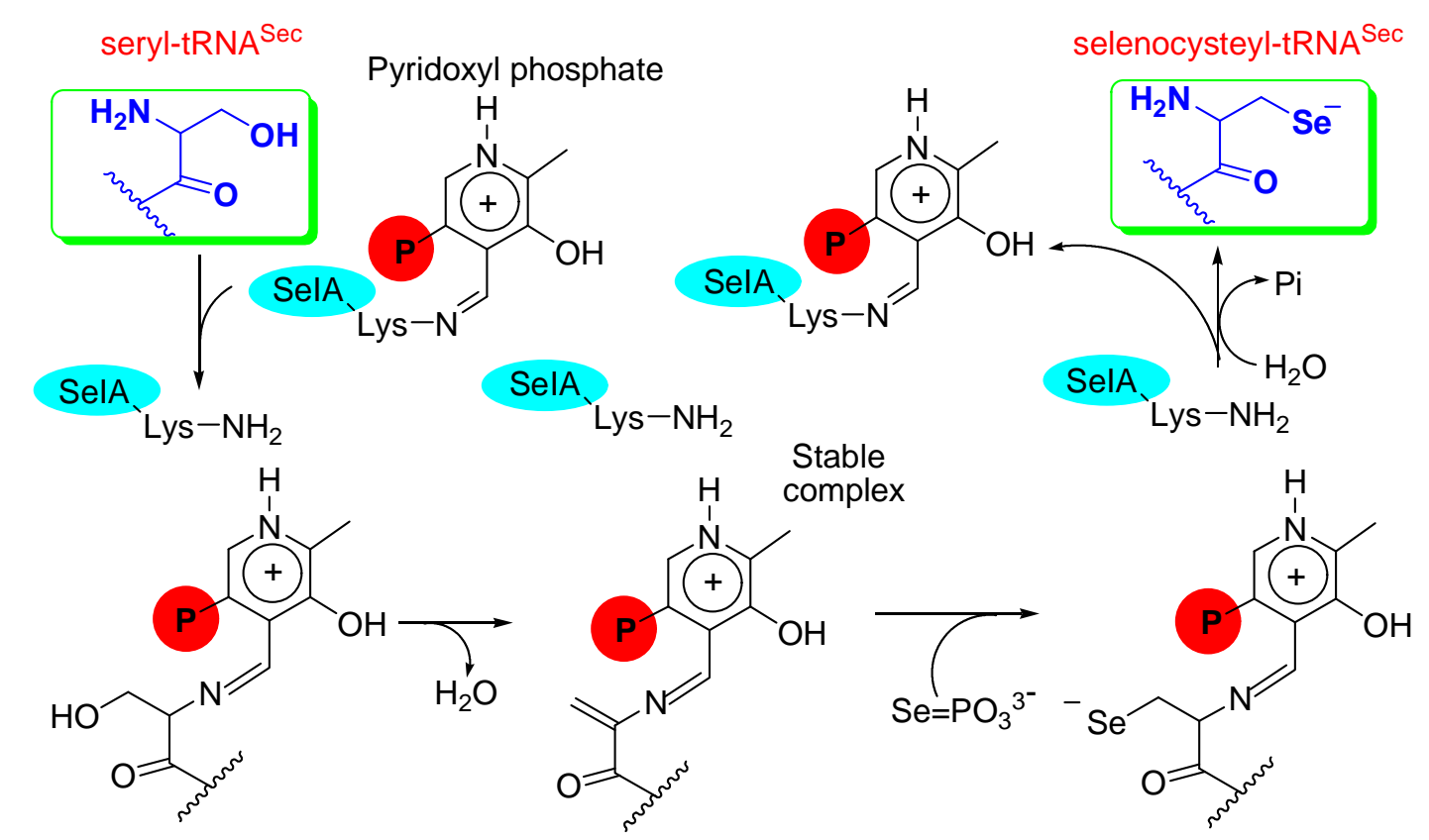

Scheme 2. Proposed reaction mechanism for the conversion of seryl-tRNA ${ }^{\text {Sec }}$ to selenocysteyl-tRNA ${ }^{\mathrm{Sec}}$ catalysed by selenocysteine synthase. ${ }^{49}$

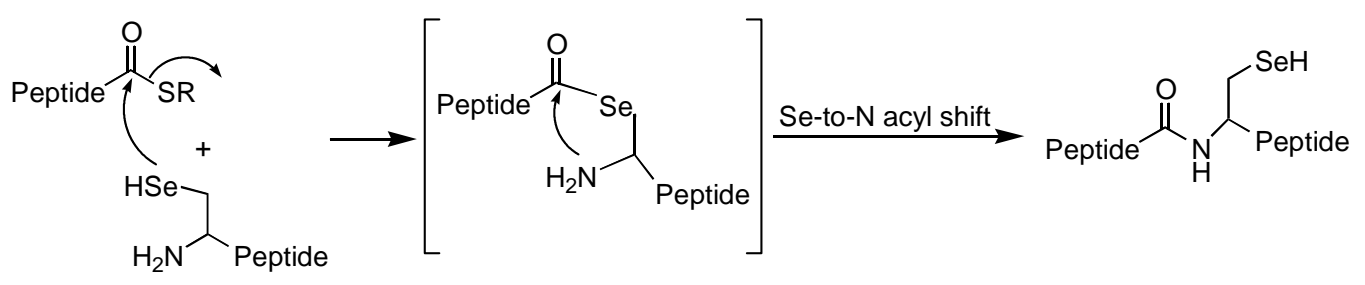

Scheme 3. Selenocysteine-mediated native chemical ligation.

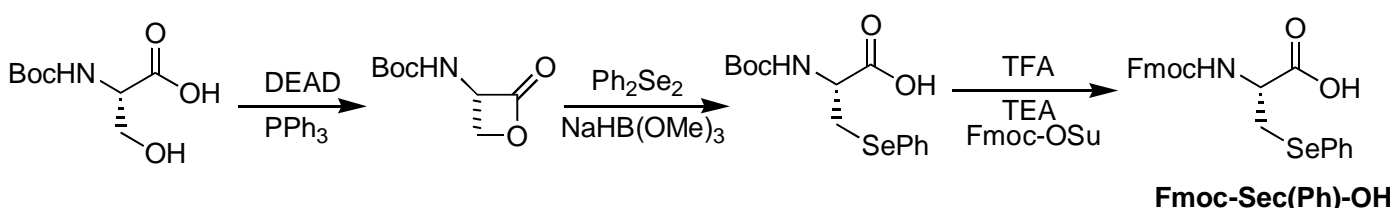

Scheme 4. Synthesis of Fmoc-Sec(Ph)-OH via L-serine- $\beta$-lactone. DEAD = diethyl-azodicarboxylate, TFA = trifluoroacetic acid, TEA = triethylamine, Fmoc-Osu $=9$-fluorenylmethoxycarbonyl succinate.

the nucleophilic displacement of a O-tosylated Lserine derivative. A later alternative approach was reported by Shirahama and co-workers who reduced diphenyl diselenide with sodium metal and reacted the resulting selenolate with tert-butoxycarbonyl (Boc) protected serine $\beta$-lactone. ${ }^{52}$ More recently, this approach has been modified by performing an in situ reduction of diphenyl diselenide with sodium trimethoxyborohydride $\left[\mathrm{NaBH}(\mathrm{OMe})_{3}\right]$ (scheme 4). ${ }^{53}$ In this latter study, the Boc group was removed, fol- lowed by 9-fluorenylmethoxycarbonyl (Fmoc) protection in a one-pot procedure to yield Fmoc-Sec $(\mathrm{Ph})-\mathrm{OH}$, which was used for automated solid-phase peptide synthesis (SPPS).

Recently, an alternative synthetic route to selenocysteine derivatives has been reported (scheme 5). ${ }^{54}$ Three orthogonal protecting groups were used for the amino, carboxylate, and selenol functionalities that allowed their independent manipulation. The free carboxylate of Fmoc-Ser was converted to the allyl 


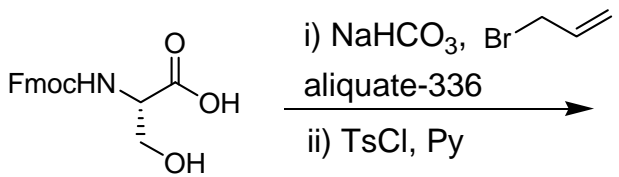

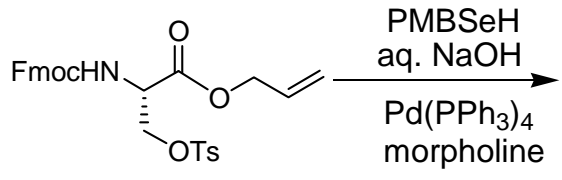

3<smiles>N#[R16][Se]C[C@H](NC(F)F)C(=O)O</smiles>

4

Scheme 5. Improved scalable synthesis of Fmoc-Sec derivatives.

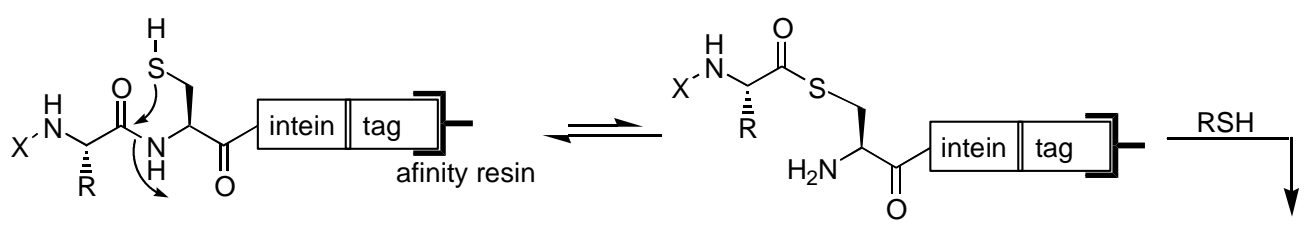

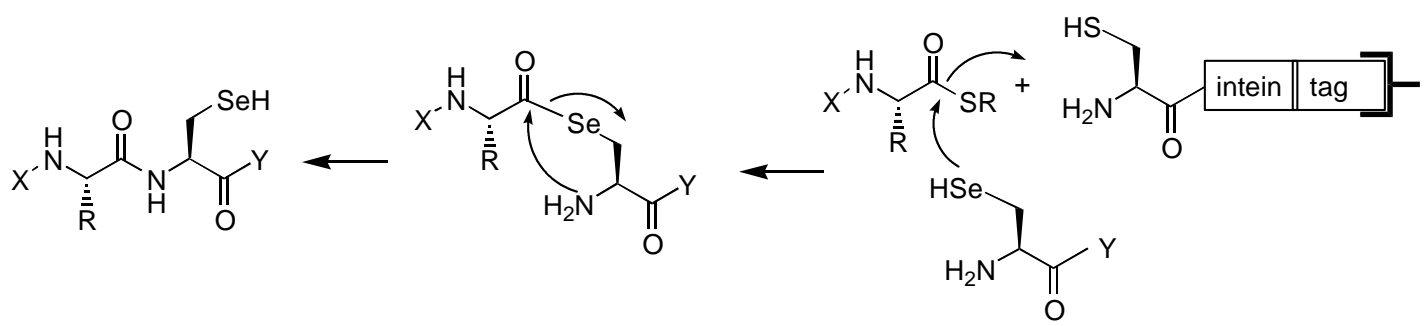

Scheme 6. Selenocysteine-mediated expressed protein ligation. $X=$ recombinant target protein truncated at its $\mathrm{C}$ terminus. $\mathrm{Y}=$ synthetic peptide corresponding to the truncated $\mathrm{C}$ terminus.

ester, followed by activation of the alcohol with $p$ toluenesulfonyl chloride to provide 3. p-Methoxybenzyldiselenide (PMBSe) $)_{2}$, obtained by treating selenium powder with super hydride followed by $\mathrm{PMBCl}$, was reduced to the selenol with hypophosphoric acid. Without further purification, the resulting selenol was added to 3 under basic conditions to yield the fully protected selenocysteine derivative. Selective deprotection of the carboxylate with catalytic palladium and morpholine gave $\mathbf{4}$ in good yield.

\subsection{Expressed protein ligation}

Expressed protein ligation (EPL), a powerful extension of native chemical ligation, was first reported in 1998 and has become increasingly popular in recent years for protein engineering. With the success of Secmediated native chemical ligation, it became clear that $\mathrm{Sec}$ could also be used at the point of ligation in expressed protein ligation. ${ }^{55}$ The process of selenocysteine-mediated EPL is briefly outlined in scheme 6. A target protein truncated at its $\mathrm{C}$ terminus is overexpressed in E. coli as a fusion to an intein domain and affinity tag (either a hexa-His tag or chitin binding domain, CBD). The cell lysate is passed through the affinity column to bind the target protein and separate it from other cellular constituents. Inteins self-catalyse a rearrangement reaction from an amide to a thioester at a cysteine residue within their sequence. When an external thiol is added to the resin, a trans-thioesterification takes place that cleaves the truncated target protein from the resin while leaving the intein attached. Addition of an unprotected synthetic peptide with $\mathrm{Sec}$ at its $\mathrm{N}$ terminus initiates another trans-thioesterification, followed by an Se-to-N acyl shift to yield a fully deprotected mutant protein with a Sec incorporated at a specific site within the polypeptide.

\section{Glutathione peroxidases (GPx)}

Glutathione peroxidases (GPx) are antioxidant selenoenzymes protecting various organisms from oxidative stresses by catalyzing the reduction of hydroperoxides at the expense of GSH. ${ }^{56,57}$ The GPx superfamily contains four types of enzymes, the classical cytosolic GPx (cGPx), phospholipid hydroperoxide GPx (PHGPx), plasma GPx (pGPx), and gastrointestinal GPx (giGPx), all of which require selenium in their active sites for the catalytic activity. ${ }^{58-62}$ The reactivity of these enzymes differs considerably depending upon the hydroperoxides and thiol cofactor. The classical GPx utilizes exclusively GSH as reducing substrate 
for the reduction of $\mathrm{H}_{2} \mathrm{O}_{2}$ and a limited number of organic hydroperoxides such as cumene hydroperoxide and tert-butyl hydroperoxide. The PHGPx also uses GSH as physiological reducing substrate, but the hydroperoxide substrate specificity is more broad. This enzyme is active on all phospholipid hydroperoxides, fatty acid hydroperoxides, cumene hydroperoxide, tert-butyl hydroperoxide, cholesterol hydroperoxides, and $\mathrm{H}_{2} \mathrm{O}_{2}{ }^{63}$ On the other hand, the hydroperoxide substrate specificity of pGPx is more restricted. Although pGPx can reduce $\mathrm{H}_{2} \mathrm{O}_{2}$ and organic hydroperoxides, it is approximately 10 times less active than the cGPx. In contrast to the cGPx, GSH is a poor reducing substrate for this enzyme. Since the concentration of reduced thiol groups in human plasma is very low, it is quite unlikely that GSH is the reducing substrate for the plasma enzyme. Alternatively, the extracellular thioredoxin reductase, thioredoxin, or glutaredoxin could be reasonable candidates. $^{64}$

The GPx catalytic site includes a Sec residue in which the selenium undergoes a redox cycle involving the selenol $(\mathrm{ESeH})$ as the active form that reduces hydrogen peroxides and organic peroxides. The selenol is oxidized to selenenic acid $(\mathrm{ESeOH})$, which reacts with reduced glutathione (GSH) to form a selenenyl sulphide adduct (ESeSG). A second glutathione then regenerates the active form of the enzyme by attacking the ESeSG to form the oxidized glutathione (GSSG) (scheme 7). Thus, in the overall process, 2 equiv of glutathione are oxidized to the disulphide and water, while the hydroperoxide is reduced to the corresponding alcohol. In the presence of an excess hydroperoxide, the selenium centre in GPx may be overoxidized to produce seleninic acid $\left(\mathrm{ESeO}_{2} \mathrm{H}\right)$ and selenonic acid $\left(\mathrm{ESeO}_{3} \mathrm{H}\right)$. However, such species are believed to lie off the main catalytic pathway.

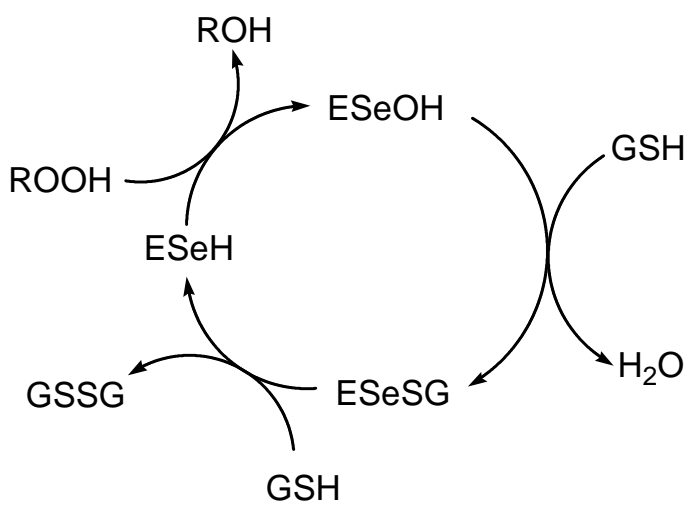

Scheme 7. Proposed catalytic mechanism for the reduction of hydroperoxides by GPx.
The arrangement of the amino acid residues in the active site of GPx shows some interesting features. It is evident from various studies that two amino acid residues, that is tryptophan and glutamine, appear in identical positions in all known members of the GPx family. ${ }^{58}$ According to the three-dimensional structure established for bovine cGPx, these residues could constitute a catalytic triad in which the selenol group of the selenocysteine is both stabilized and activated by hydrogen bonding with the imino group of the tryptophan (Trp) residue and with the amido group of the glutamine (Gln) residue (figure 1) ${ }^{65}$ The crystal structure of human plasma GPx has also been determined and crystallographically refined at $2.9 \AA$ resolution. ${ }^{66}$ Although the overall active site architecture of the human plasma enzyme is similar to that of the cytoplasmic enzyme, the environment close to the selenocysteine residues is quite different in the two enzymes. Approximately only half of the residues close to the selenocysteine residue within a range of $10 \AA$ are conserved in both enzymes. The residues conserved in the human plasma enzyme are Phe76, Gln79, Arg95, Trp153, Phe155, Asn154 and Arg173. Of these residues, Gln79 and Trp153 are located within hydrogen bonding distance of the selenium atom and have been suggested to play functional roles in catalysis. As mentioned already, these two residues are in fact conserved in the whole GPx superfamily and probably account for the similarities in their catalytic mechanisms.

The chemical aspects of the reduction of hydroperoxide by GPx have been extensively studied with the help of model compounds. These include antiinflammatory drug ebselen, a variety of substituted diaryl selenides and diselenides, N-Se heterocycles, the artificial selenoenzyme selenosubtilisin, selenopeptides, and other types of selenium compounds. ${ }^{67-78}$ Hilvert et al have shown that the reduced form of selenosubtilisin is strongly stabilized by nearby histidine residues. ${ }^{79}$ Because the enzyme-bound selenol is

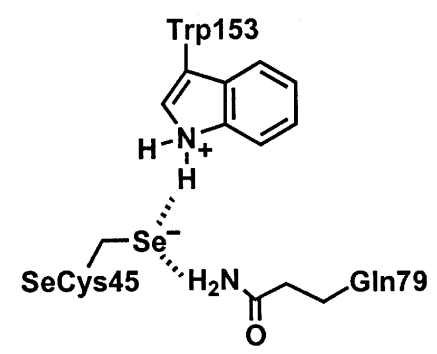

Figure 1. The active site of GPx showing Sec-Trp-Gln catalytic triad. 


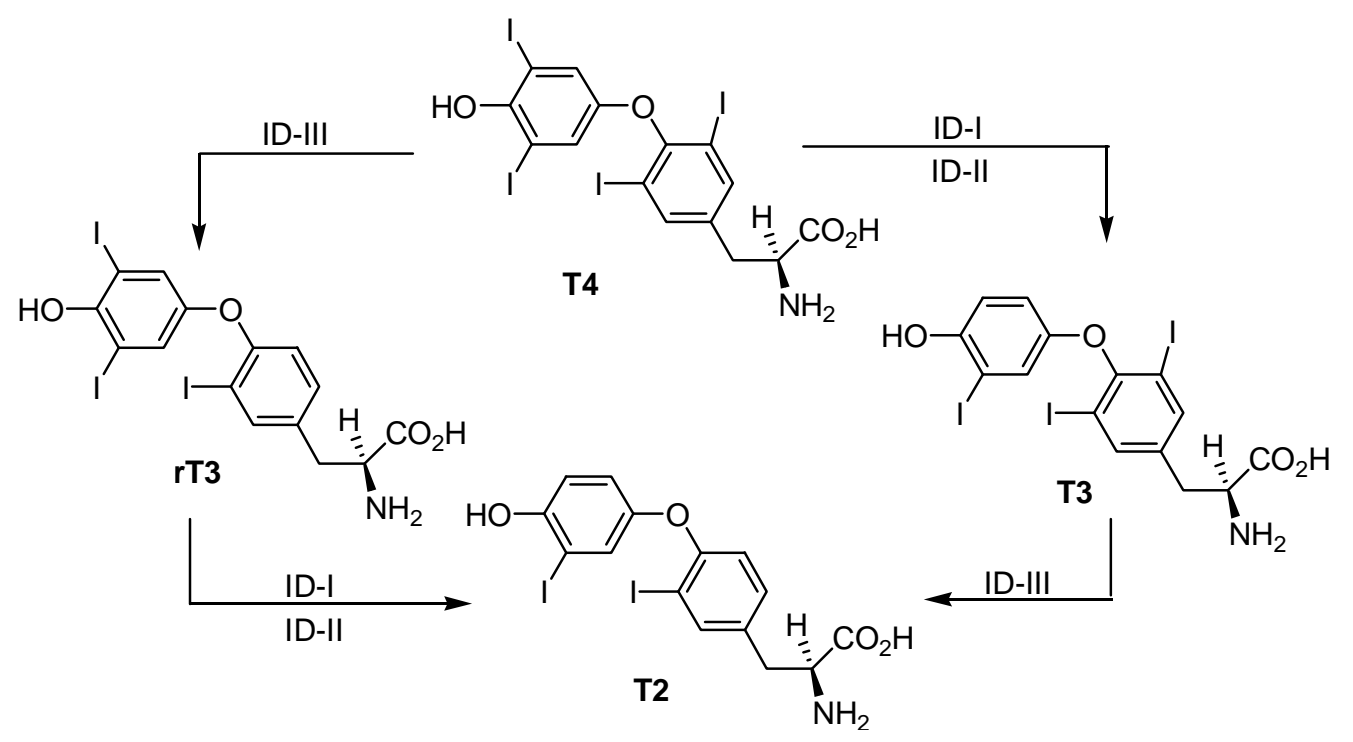

Scheme 8. Biochemical deiodination of thyroxine catalysed by iodothyronine deiodinases.

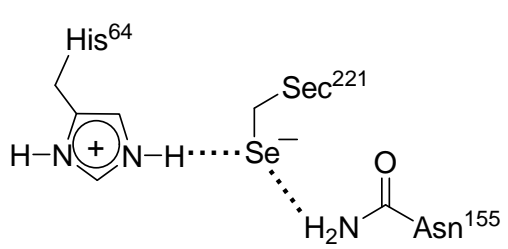

Figure 2. Stabilization of the selenolate form of selenosubtilisin.

deprotonated by His64 to form a selenolate-imidazolium ion pair at all accessible $\mathrm{pH}$ values, it is expected to be highly reactive and therefore susceptible to oxidation by hydroperoxides. Another amino acid residue, Asn155, is also expected to play an important role in the stabilization of the selenolate (figure 2). Similarly, the active site selenol (Sec149) in selenoGAPDH interacts with a histidine residue (His176) to form an efficient selenolate-imidazolium ion pair. ${ }^{79}$ In agreement with the role of Trp and Gln in GPx catalysis and the importance of His residues in the reduction of hydroperoxides by selenosubtilisin, basic amino groups in the close proximity to selenium have been shown to play a significant role in modulating the antioxidant properties of synthetic selenium compounds. $^{78}$

\section{Iodothyronine deiodinases (ID)}

The thyroid gland, in response to stimulation by TSH, produces thyroxine (T4) as the main secretory product that undergoes enzymatic outer-ring deiodination to produce the biologically active hormone, 3,5,3'-triiodothyronine (T3), and this reaction is catalysed by type I iodothyronine deiodinase (ID-I), a selenocysteinecontaining integral membrane enzyme ${ }^{80}$ present in the highest amounts in liver, kidney, thyroid and pituitary. The thyroid gland also produces an inactive metabolite rT3 by inner ring deiodination. The triiodo derivatives T3 and rT3 are further metabolized by inner ring and outer ring deiodination, respectively, by ID-I, ID-II and ID-III to produce the inactive metaboilite T2 (3,3'-T2, 3,5-T2 and 3',5'-T2) (scheme 8).

The $5^{\prime}$-deiodination catalysed by ID-I is a pingpong, bisubstrate reaction in which the selenol (or selenolate) group of the enzyme (E-SeH or $\mathrm{E}_{-} \mathrm{Se}^{-}$) first reacts with thyroxine (T4) to form a selenenyl iodide (E-SeI) intermediate. Subsequent reaction of the selenenyl iodide with an as yet unidentified intracellular cofactor (DTT in vitro) completes the catalytic cycle and regenerates the enzyme active site (scheme 9). It is known that the anti-thyroid drug, 6- $n$-propyl-2-thiouracil (PTU), inhibits the activity of the enzyme probably by reacting with the selenenyl iodide intermediate and the gold-containing drugs such as gold thioglucose (GTG) inhibits the deiodinase activity by reacting with the selenol group of the native enzyme.

\section{Anti-thyroid drugs}

As mentioned in the previous section, in healthy humans the thyroid gland produces predominantly the prohormone $\mathbf{T 4}$, which is enzymatically deiodinated 


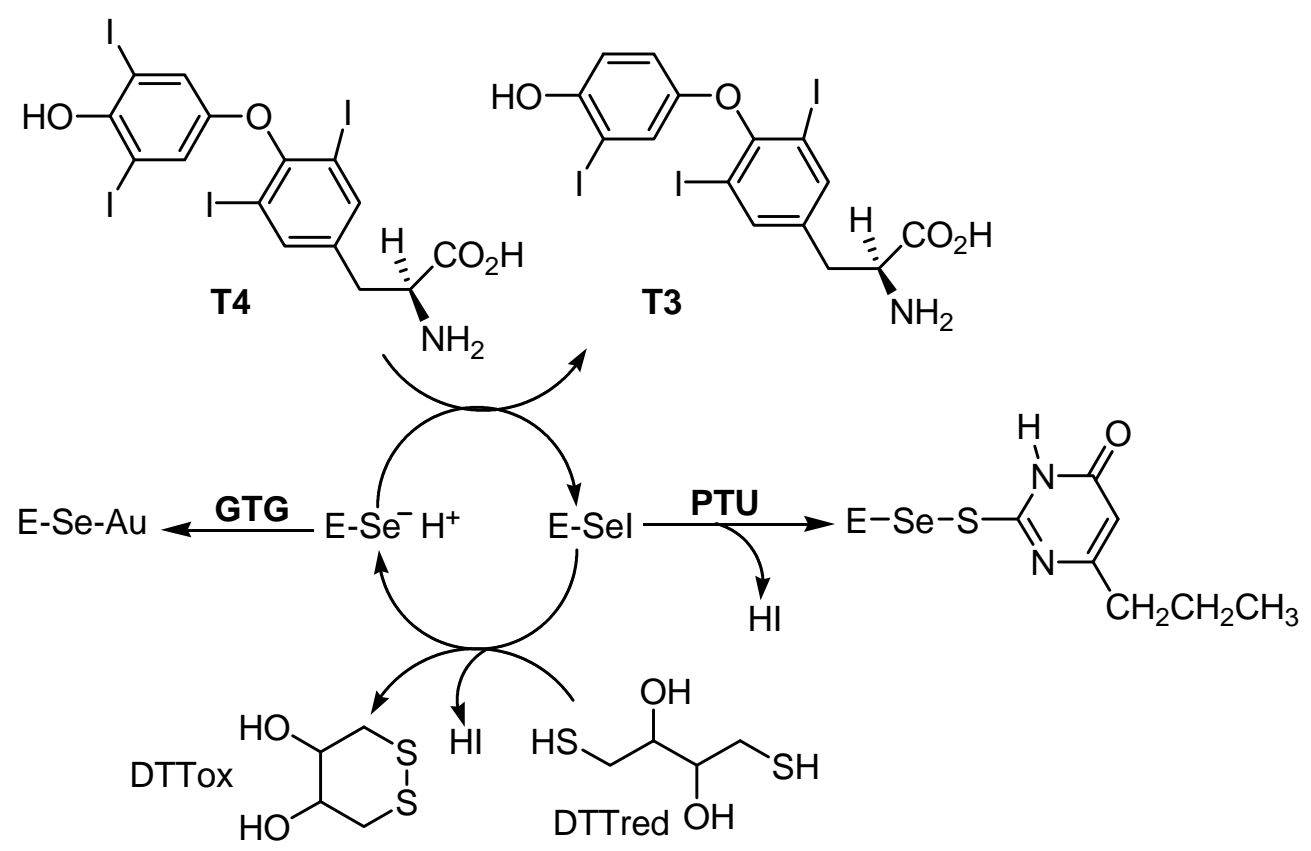

Scheme 9. Proposed mechanism for the deiodination of thyroxine by ID-1 and inhibition of ID-1 by $n$-propyl-2-thiouracil (PTU) and gold thioglucose (GTG).

to provide the biologically active hormone $\mathrm{T} 3$ and other inactive species. Although the enzymatic deiodination is important for the functioning of the thyroid gland, the activation of thyroid-stimulating hormone (TSH) receptor by auto-antibodies leads to an overproduction of thyroid hormones. In addition, these auto-antibodies also stimulate ID-I and probably IDII, which then together produce relatively more T3. As these antibodies are not under pituitary feedback control, no negative influence on thyroid activity is exerted and therefore hyperthyroidism persists. Under these conditions, the overproduction of $\mathbf{T} 3$ is controlled by specific inhibitors, which either block the thyroid hormone biosynthesis or reduce the conversion of T4 to T3. An interesting class of such inhibitors is the thiourea drugs, 6- $n$-propyl-2-thiouracil (5, PTU), 6-methyl-2-thiouracil (6, MTU), methimazole (7, MMI) and carbimazole (8, CBZ).<smiles>[R]c1cc(=O)[nH]c(=S)[nH]1</smiles><smiles>Cn1cc[nH]c1=S</smiles><smiles>CCOC(=O)n1ccn(C)c1=S</smiles>

5, $\mathrm{R}=n \mathrm{Pr}$ 6, $R=M e$

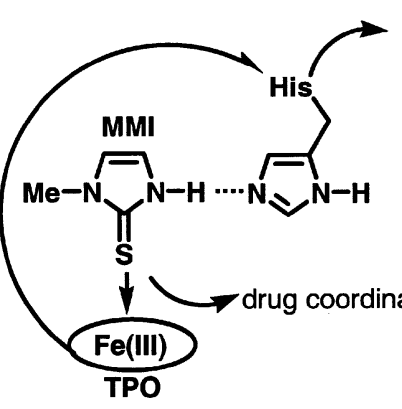

histidine residue of TPO enzyme

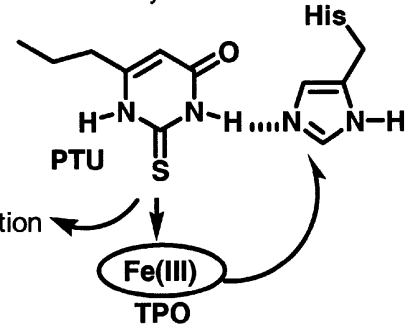

Figure 3. A hypothetical model for the coordination of thiourea drugs to the Fe-centre of TPO.

hyperthyroidism, the detailed mechanism of their action is still not clear. According to the initially proposed mechanism, these drugs form stable electron donoracceptor complexes with diiodine and divert oxidized iodides away from thyroglobulin, which effectively reduces the thyroid hormones biosynthesis. ${ }^{81}$ It has been proposed in the second mechanism that these drugs coordinate to the thyroid peroxidase (TPO), a heme enzyme which catalyses the oxidation of iodides and the coupling of iodothyrosine residues of thyroglobulin, thereby blocking the thyroid hormone synthesis (figure 3). ${ }^{82}$
Although these compounds are the most commonly employed drugs for the treatment of patients with 


\section{Inhibition of iodothyronine deiodinases}

After the discovery that the ID-I is responsible for the activation of thyroxine, it has been reported that PTU can also block the conversion of T4 to T3 by reacting with the selenenyl iodide intermediate (ESeI) of ID-I to form a selenenyl sulphide (figure 4) as a dead end product. ${ }^{83}$ Interestingly, PTU does not block the activity of other two selenoenzymes (ID-II and ID-III) under normal conditions and the reason for the insensitivity of PTU towards these two enzymes is still unknown. Recent biomimetic studies on the inhibition of ID by anti-thyroid drugs have been focused on three aspects: (i) Experimental verification for the mechanism of the inhibition of ID-I by PTU and MTU, (ii) identification of the possible reason for the insensitivity of certain deiodinases towards PTU and MTU, (iii) possible explanation for the lower inhibitory activity of MMI towards ID-I compared with that of PTU and MTU. ${ }^{84}$

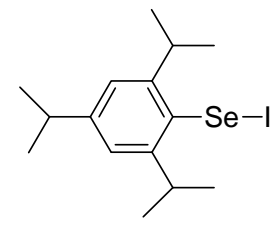

9

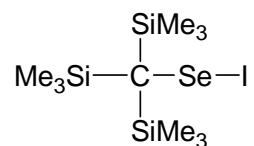

10

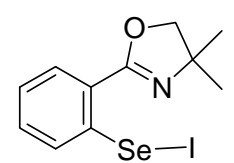

11

The reactivity of Se-I species towards anti-thyroid drugs has been experimentally verified by du Mont et $a l^{84}$ with the help of synthetic selenenyl iodides. When "PhSel" $\left(0.5 \mathrm{Ph}_{2} \mathrm{Se}_{2} . \mathrm{I}_{2}\right)$ and 9 , which are known to disproportionate in solution to diselenide and iodine or their adducts, were treated independently with stoichiometric amounts of PTU or 6-methyl-2-thiouracil (MTU) in the presence of triethylamine, both the reactions afforded the corresponding diselenides, rather than the selenenyl sulphides, as the only products. ${ }^{84 a}$ This indicates that the unstable selenenyl iodides $\mathrm{PhSeI}$ and 9 are reduced by PTU and MTU to the corresponding diselenides (and not the PTU/MTU derivatives). These properties of $\mathrm{PhSeI}$ and 9 therefore

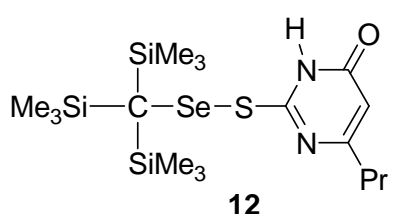

12

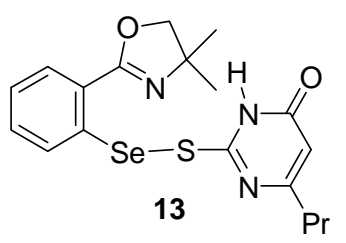

Figure 4. Synthetic models for the Se-I intermediate of ID-I. resemble the inhibitory action of PTU-insensitive deiodinases. In the absence of triethylamine, selenenyl iodide $\mathbf{1 0}$ reacted with PTU and MTU much more slowly than the internally chelated compound $\mathbf{1 1}$. Although compound $\mathbf{1 1}$ reacted rapidly with PTU and MTU under similar experimental conditions, it unexpectedly afforded the corresponding diselenide as the major product. This result indicates that the $\mathrm{HI}$ produced during the reaction may act as a catalyst for the diselenide formation. However, in the presence of triethylamine, no diselenide is formed and both $\mathbf{1 0}$ and $\mathbf{1 1}$ reacted rapidly with PTU and MTU to give the desired selenenyl sulphides $\mathbf{1 2}$ and $\mathbf{1 3}$, respectively (figure 4). ${ }^{84}$

The crucial amino-acid residues responsible for binding inhibitors or the details concerning the nature of enzyme-inhibitor interactions have not yet become available. A careful analysis of the active site features of ID-I reveals that the presence of $\mathrm{N}-\mathrm{H}$ groups in the thiourea drugs is essential not only for the reactivity of the drugs but also for the stability of the selenenyl sulphide adducts formed with the enzyme. The potent inhibitory effects of PTU and MTU towards ID-I may be due to the presence of $-\mathrm{N}(\mathrm{H})-\mathrm{C}(=\mathrm{O})$ - functionality that could form hydrogen bonds with nearby amino acid residues after the formation of a stable selenenyl sulphide, making the active site not accessible for further reactions. In contrast, MMI does not have any additional N-H groups after the formation of a selenenyl sulphide and therefore cannot exhibit any stabilizing interactions with the nearby amino acid residues. In agreement with this, the crystal structure of 12 shows that the Se-S bond in this compound is stabilized by intermolecular hydrogen bonds (figure 5).

\section{Thioredoxin reductases (TrxR)}

Thioredoxin reductase (TrxR, EC 1.6.4.5) is a member of the pyridine nucleotide-disulphide oxidoreductase family. ${ }^{85}$ Enzymes of this family, such as glutathione reductase (GR), lipoamide dehydrogenase, and trypanothione reductase, form homodimers, and each subunit contains a redox-active disulphide bond and a tightly bound FAD molecule. TrxR catalyses reduction of thioredoxins (Trx) by NADPH. Trxs are a group of small (10-12 kDa) ubiquitous redox-active proteins, which have a conserved Trp-Cys-Gly-Pro-Cys-Lys- catalytic site that undergoes reversible oxidation-reduction of the two Cys residues. The redox activity of this catalytic site is necessary for the biological activity of $\operatorname{Trx} .^{86,87}$ 


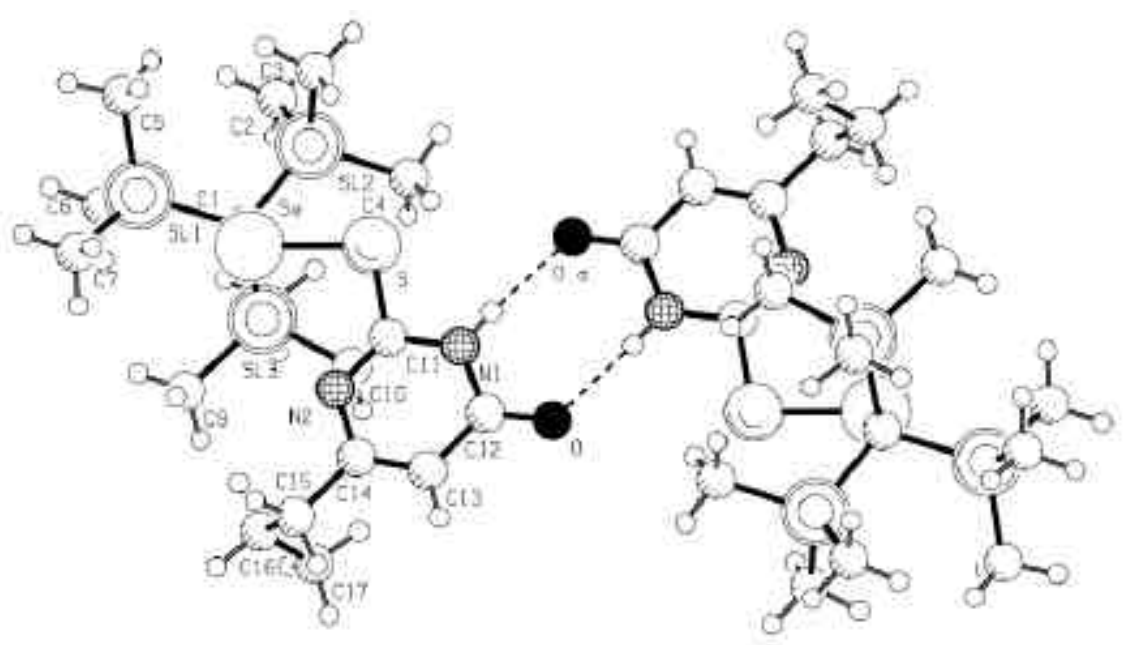

Figure 5. The crystal structure of 12, showing intermolecular hydrogen bonds. ${ }^{84}$

Table 2. Roles of Trx in mammals.

\begin{tabular}{lc}
\hline Role & \multicolumn{1}{c}{ Comments } \\
\hline $\begin{array}{l}\text { Redox regulation of transcription } \\
\text { factors, e.g. NFkB, AP-1 }\end{array}$ & $\begin{array}{c}\text { Different transcription factors are either activated or inhibited by } \\
\text { Trx, which also may exert different activities in nucleus } \\
\text { compared to cytosol }\end{array}$ \\
Regulation of apoptosis & $\begin{array}{c}\text { Trx makes a complex with ASK1, prevents downstream signaling } \\
\text { for apoptosis } \\
\text { Immunomodulation }\end{array}$ \\
Extracellular Trx is both a co-cytokine and chemokine and a \\
truncated form stimulates eosinophiles \\
Intracellular and extracellular synthesis of Trx from cytotropho- \\
blasts assist implantation and establishment of pregnancy \\
Birth
\end{tabular}

Although it is beyond the scope of this review to thoroughly describe all of the functions of mammalian Trx proteins, some of the major functions are to supply reducing equivalents to enzymes such as ribonucleotide reductase and thioredoxin peroxidase, and, through thiol-disulphide exchange, to reduce key Cys residues in certain transcription factors, resulting in their increased binding to DNA and altered gene transcription (table 2 ). ${ }^{88}$

TrxR-catalysed reduction of Trx utilizes NADPH as cofactor. The reduced form of Trx provides reducing equivalents to (i) Trx peroxidase, which breaks down $\mathrm{H}_{2} \mathrm{O}_{2}$ to water, (ii) ribonucleotide reductase, which reduces ribonucleotides to deoxyribonucleotides for DNA synthesis, and (iii) transcription factors, which leads to their increased binding to DNA and altered gene transcription (figure 6). In addition, Trx increases cell growth and inhibits apoptosis. The mammalian TrxRs have a higher molecular mass $(55 \mathrm{kDa})$ and a very broad substrate specificity in contrast to the smaller $(35 \mathrm{kDa})$ specific enzymes represented by the well-characterized $E$. coli TrxR. ${ }^{89}$ The mammalian enzymes are selenoenzymes, which can react not only with Trx from different species but also with a variety of non-disulphide substrates, such as selenoglutathione, selenite, ascorbic acid, $S$-nitrosoglutathione, hydroperoxides and peroxynitrite. ${ }^{90}$ The presence of Sec in the these enzymes is essential because its replacement with Cys results in a mutant rat TrxR enzyme with about $1 \%$ activity with Trx as substrate. $^{91,92}$

The mammalian TrxRs possess two redox active centres: One consisting of Cys59/Cys64 adjacent to the flavin ring of FAD and the other consisting of 


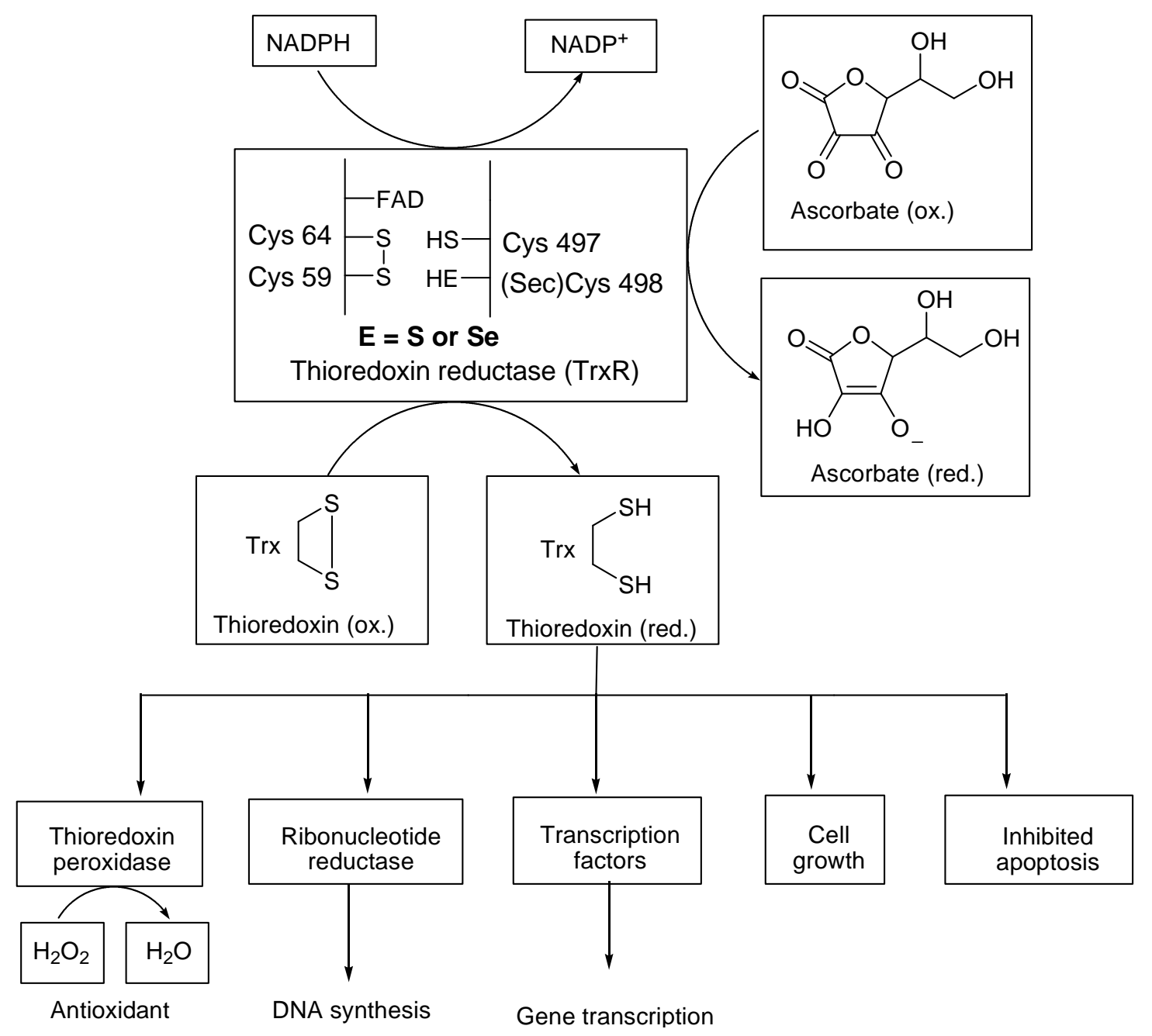

Figure 6. Functions of $\operatorname{TrxR}$ in the cell.

Cys497/Sec498 near the C-terminus. The proposed mechanism for the reduction of Trx by TrxR is summarized in scheme 10. According to this mechanism, the first step is the reduction of the selenenyl sulphide to produce the corresponding selenol (or selenolate). The selenol (or selenolate anion) attacks the disulphide bond of Trx, resulting in the formation of a TrxR-Trx-mixed selenenyl sulphide. The $\mathrm{Se}-\mathrm{S}$ bond in this intermediate is cleaved by Cys 497 to regenerate the selenenyl sulphide, which could be reduced further by the Cys residue of the nearby subunit. In this conversion, the conserved Cys-497Sec-498 motif acts as a second redox centre and the electrons are transferred from the redox-active disulphide via the redox centre at the $\mathrm{C}$ terminal to the substrate, Trx. ${ }^{91-93}$

The conformation of the C-terminal can be modelled in such a way that it approaches the redox-active di- sulphide $\mathrm{Cys}^{59}-\mathrm{Cys}^{64}$ close enough for electron transfer without steric clashes, decreasing the distance between $\mathrm{Cys}^{59}$ and $\mathrm{Cys}^{497}$ from $12 \AA$ to $3 \AA$. This conformational change involves mainly residues $\mathrm{Ser}^{495}$-Cys, ${ }^{498}$ where the largest movement is that of $\mathrm{Cys}^{497}$ (about a 5- $\AA$ displacement of the $\mathrm{C} \alpha$-atom). The charge interaction between the C-terminal carboxyl group of Gly ${ }^{499}$ and the side chain of $\mathrm{Lys}^{29}$ can be maintained in the two conformations. A careful analysis of the active site features of mammalian TrxR mutant reveals that one or more histidine residues near the $\mathrm{Se}-\mathrm{S}$ and $\mathrm{S}-\mathrm{S}$ bonds may play crucial roles in the catalysis (figure 7).

In such a model of the oxidized form of the Cys ${ }^{497}$ $\mathrm{Sec}^{498}$ motif, the selenium atom would be located very close to the side chain of the conserved $\mathrm{His}^{472}$, and the imidazole group could participate in proton transfer to $\mathrm{Cys}^{497}$. After reduction, the C-terminal tail 


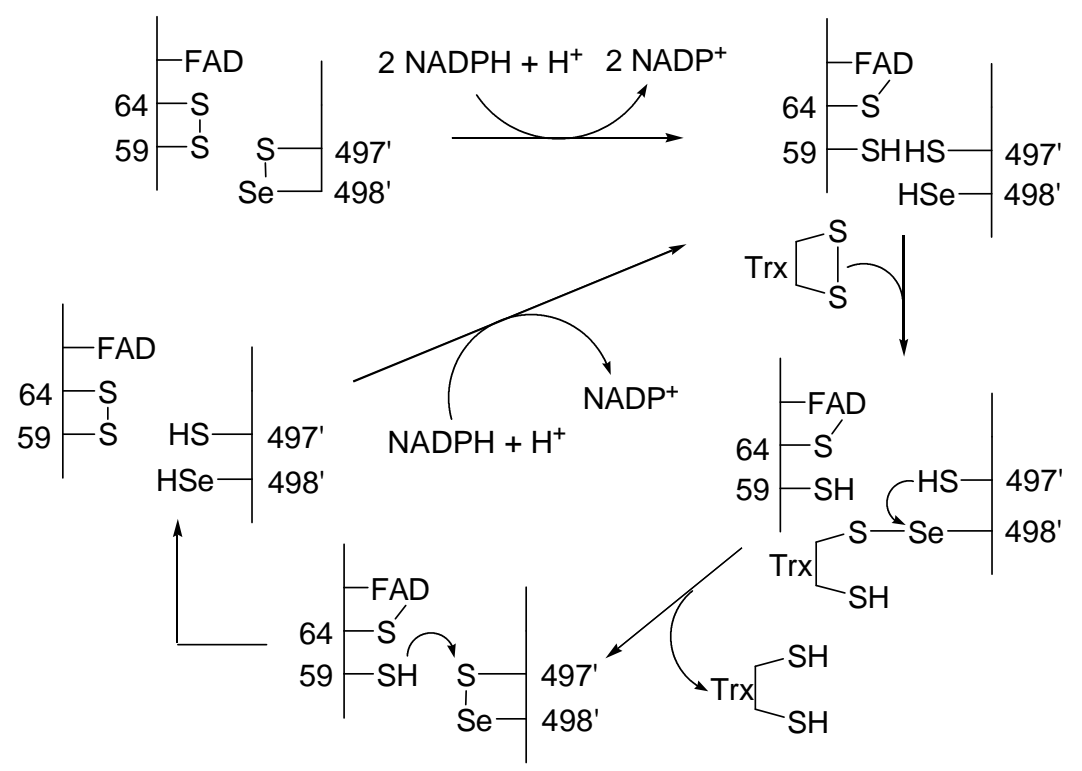

Scheme 10. Proposed catalytic mechanism for the reduction of Trx by mammalian TrxR.

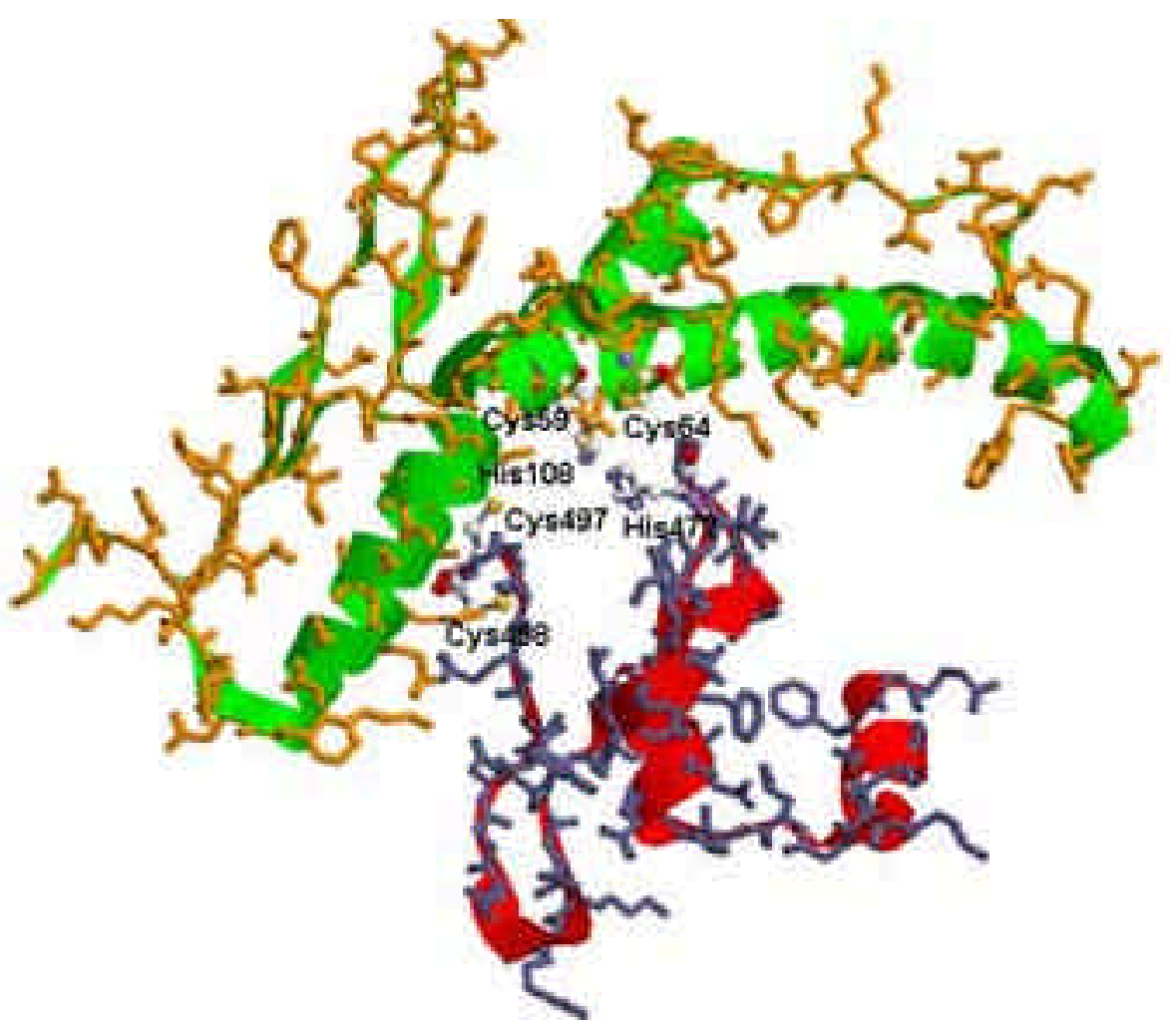

Figure 7. The active site of the Sec498Cys mutant of rat TrxR (PDB code: 1H6V). ${ }^{85}$

could then move away from the catalytic site to a position at the surface of the enzyme and interact with the bound substrate, Trx. The model of the TrxRTrx complex is consistent with a mechanistic scenario for the dithiol-disulphide exchange reaction put forward previously. ${ }^{92}$ In this step of the reaction, the selenolate anion attacks the disulphide of Trx. The resulting enzyme, Trx-mixed selenenyl sulphide, is then attacked by $\mathrm{Cys}^{497}$ to regenerate the selenenyl sulphide. 


\subsection{Reduction of hydroperoxides by Trx system}

A number of recent studies suggest that the mammalian Trx system can reduce hydroperoxide substrates and thus mimic the properties of GPx. As already mentioned, the hydroperoxide substrate specificity of plasma GPx is highly restricted. This enzyme can reduce $\mathrm{H}_{2} \mathrm{O}_{2}$ and organic hydroperoxides, but its activity was found to be much lower than that of the cGPx. In addition, the tripeptide GSH is a poor reducing substrate for this enzyme. This led to the assumption that TrxR, Trx, or glutaredoxin may be involved in the reduction of peroxides by the plasma enzyme. ${ }^{64}$ In agreement with this, Holmgren et $a l^{94}$ have shown that human TrxR and NADPH in the presence or absence of Trx serve as efficient electron donors to human GPx. In addition, they have also shown that the human placenta TrxR directly reduces lipid hydroperoxides by NADPH and the rate of this reaction can be accelerated by the addition of selenocystine. ${ }^{95}$ It is believed that the catalytic mechanism proceeds through the formation of a catalytically active selenol, which is produced by the reduction of the diselenide bond in selenocystine by TrxR.

Holmgren et $a l^{96}$ have proposed the mechanism for the reduction of lipid peroxides and $\mathrm{H}_{2} \mathrm{O}_{2}$ by the mammalian Se-containing TrxR (scheme 11), which is similar to the mechanism proposed for the reduction of Trx. According to this mechanism, the selenenyl sulphide form of the enzyme receives an electron from NADPH to cleave the $\mathrm{Se}-\mathrm{S}$ bond and produce the selenol-thiol form. Because the selenol is expected to be dissociated and more nucleophilic than the thiol group, the selenol (or selenolate) can reacts with $\mathrm{H}_{2} \mathrm{O}_{2}$

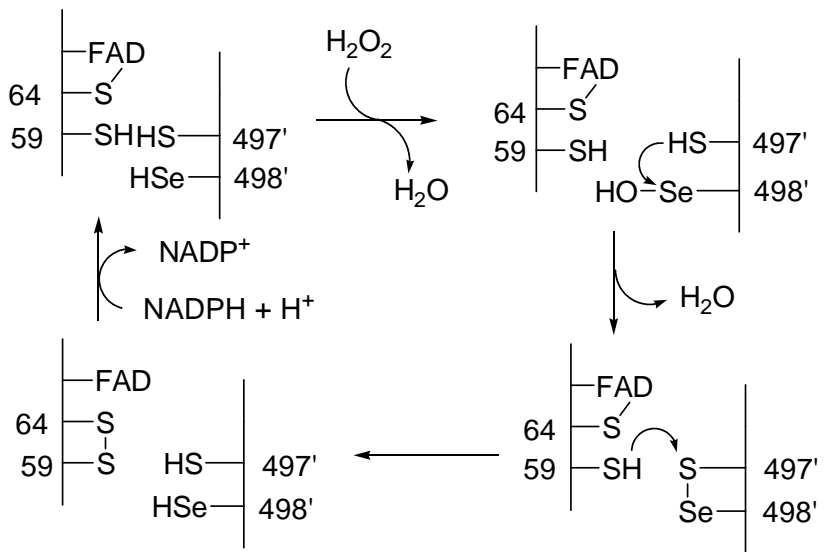

Scheme 11. Proposed mechanism for the reduction of hydroperoxides by mammalian TrxR. much faster than the thiol to produce the corresponding selenenic acid $(\mathrm{E}-\mathrm{SeOH})$. The next step of the catalytic cycle should be the attack of one of the cysteine thiols (most likely Cys497) at the selenenic acid to produce water and to reform the selenenyl sulphide. A second thiol (most likely Cys59 from the other subunit) would attack the $\mathrm{Se}-\mathrm{S}$ linkage to regenerate the selenol.

\subsection{Thioredoxin reductase as drug target}

The Trx system is of medicinal interest due to its inherent role as a broad based indicator of diseases such as AIDS, rheumatoid arthritis, and certain forms of cancer and represents an attractive target for further pharmacological examination. In recent years, the biological screening has led to the identification of a number of small organic and organometallic compounds as chemotherapeutic inhibitors of TrxR (figure 8). ${ }^{97}$ Although the early studies have shown that nitrosoureas such as BCNU can be effective irreversible inhibitors of TrxR, ${ }^{98}$ these compounds are quite toxic, relatively non-selective, and known to alkylate DNA. However, certain alkyl 2-imidazolyl disulphides such as PX-12 and the symmetrical cyclopentanone NSC 131233 have been found to be good inhibitors through screening by a COMPARE analysis from over 50,000 compounds tested by the National Cancer Institute. PX-12 is currently in Phase I clinical trials and demonstrated antitumor activity in immunodeficient mice xenograft models. ${ }^{99}$ Some of the clinically used drugs that act on TrxR are summarized in table 3 .

Halonitrobenzenes such as 1-chloro-2,4-dinitrobenzene irreversibly inhibit the human TrxR with a concomitant induction of an NADPH oxidase activity, producing superoxide (scheme 12). ${ }^{107} \mathrm{~A}$ model explaining the reactivity of dinitrohalobenzenes with thioredoxin reductase is presented, involving dinitrophenyl-derivatization of both the selenocysteine residue and its neighbouring cysteine residue, reduction by NADPH of the enzyme-bound flavin in dinitrophenyl-alkylated enzyme (DNB-TrxR), followed by two consecutive one-electron transfers from the flavin to nitro groups of the DNB-moieties in DNB-TrxR, forming nitro anion radicals. The nitro radicals react with oxygen to form superoxide, again generating dnpTrxR with an oxidized flavin, which may then follow another cycle of NADPH-dependent superoxide production. Halodinitrobenzenes are well known for their immunostimulatory properties. Here it is proposed that the inflammatory components of this immuno- 
<smiles>[R12][R12]#N</smiles><smiles>OC[C@H]1OC(S[AlH2])[C@@H](O)[C@H](O)[C@H]1O</smiles><smiles>CCOC(=O)OC1C(COC(C)=O)OC(COC(C)=O)C(OCC)C1OC(C)=O</smiles>

Figure 8. Chemotherapeutic inhibitors of the Trx/TrxR system.

Table 3. Clinically applied drugs with postulated effects on TrxR.

\begin{tabular}{|c|c|c|}
\hline TrxR inhibitor & Comment & Ref. \\
\hline $\begin{array}{l}\text { Carmustine (BCNU) and } \\
\text { other nitrosoureas }\end{array}$ & $\begin{array}{l}\text { Very effective irreversible TrxR inhibitors; however, not selective, } \\
\text { since mechanistically related enzymes are also inactivated and } \\
\text { DNA is alkylated }\end{array}$ & 100 \\
\hline Cisplatin & $\begin{array}{l}\text { Consistently, high Trx-levels appear to be involved in cisplatin } \\
\text { resistance }\end{array}$ & 101 \\
\hline Anthracyclines & $\begin{array}{l}\text { The inhibitory effects published for the rat enzyme were not } \\
\text { reproducible with the human enzyme in our hands }\end{array}$ & 102 \\
\hline Azelaic acid (dicarboxylic acids) & $\begin{array}{l}\text { The original studies were partly conducted with } E \text {. coli enzyme. } \\
\text { We found no inhibition of human h-TrxR }\end{array}$ & 103 \\
\hline 13-cis-Retionic acid & $\begin{array}{l}\text { Results obtained with } E \text {. coli enzyme were mixed with data from } \\
\text { human enzyme. All-trans retionic acid increases TrxR levels } \\
\text { when apoplied with interferon }\end{array}$ & 103,104 \\
\hline 1-Chloro-2,4-dinitrobenzene & Experimental drug in dermatology with promises for clinical use & $102,103,105$ \\
\hline ATG, Auranofin & $\begin{array}{l}\text { Selective tight-binding inhibitors, the formal } \mathrm{K}_{\mathrm{i}} \text { for auranofin } \\
\text { being } 4 \mathrm{nM}\end{array}$ & 106 \\
\hline
\end{tabular}

stimulation can be mediated by interaction with the thioredoxin system, via effects on cell function by superoxide production, oxidative stress and increased extracellular levels of thioredoxin.

Organic gold complexes such as aurothioglucose (ATG), auranofin, which are commonly used for the treatment of rheumatoid arthritis, were also discovered to be potent inhibitors of $\operatorname{Trx} / \operatorname{TrxR} .^{106}$ It has been shown that the gold free thioglucose moiety in these compounds does not inhibit the enzyme. Furthermore, gold-chelating agents such as BAL prevent and reverse the inhibition of TrxR caused by three different compounds that have only the gold moiety in common. From these studies it is clear that the binding of gold and not the organic moiety to the enzyme is responsible for the inhibition of TrxR. It is known that selenols can bind heavy metal ions much stronger than thiols. This leads to an assumption that the C-terminal redox-active $\mathrm{Cys}^{497} / \mathrm{Sec}^{498}$ centre of TrxR may be the target of the inhibitors. ${ }^{107}$ In agreement with this, the structurally and mechanistically closely related but selenium-free enzyme GR has been found to be far less sensitive to the inhibition by gold complexes.

\section{Summary and future perspectives}

The research progress in the biochemistry of selenium over the last two decades led to the identification, cloning and functional characterization of a number of selenoenzymes with widely varied catalytic potential, and the key events of selenoprotein biosynthesis have been elucidated. The biomimetic studies on seleno- 


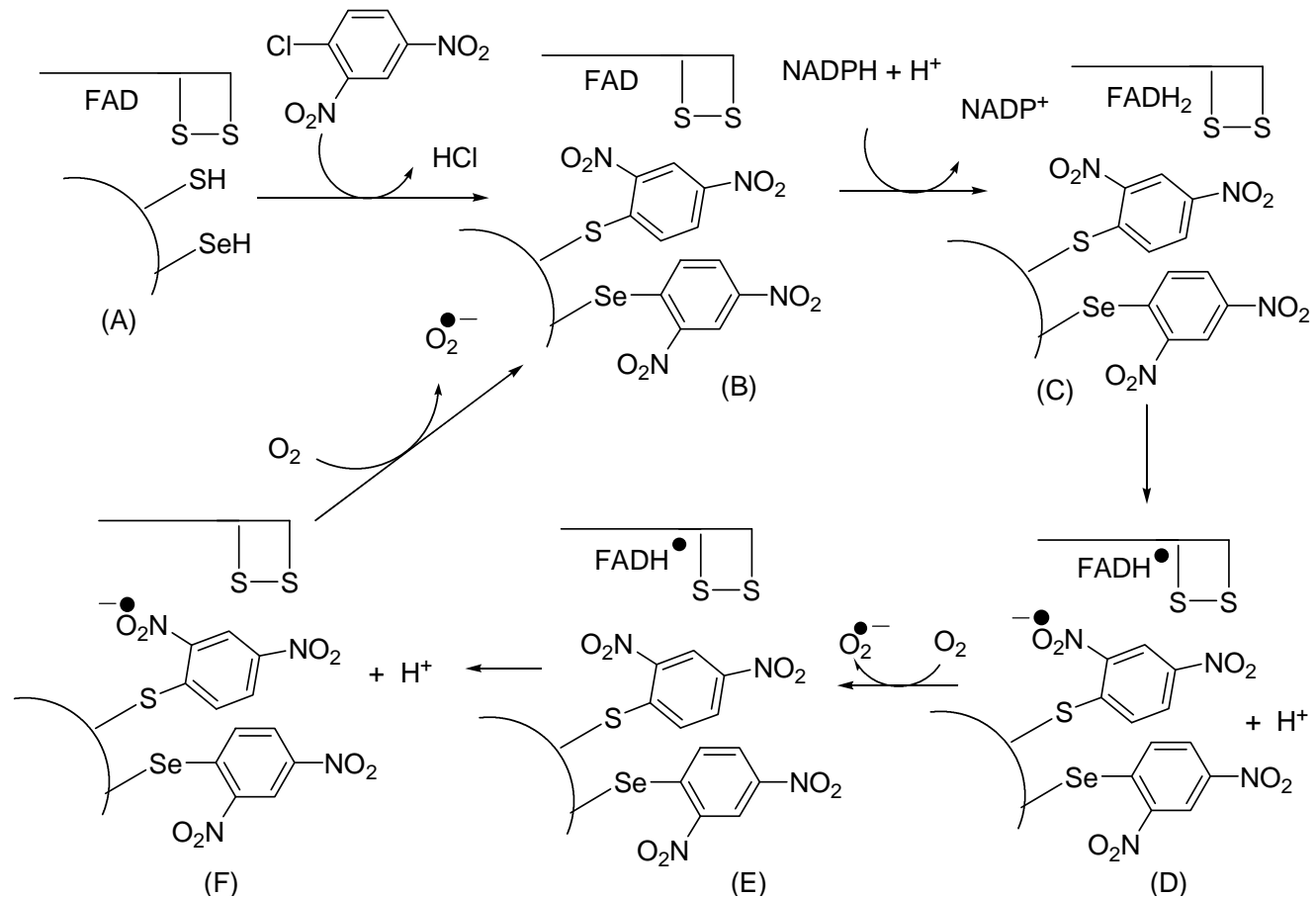

Scheme 12. Production of superoxide by TrxR. ${ }^{107}$

enzymes have been focused mainly on glutathione peroxidase (GPx) due to the fact that the structure and catalytic mechanism of this enzyme is well known. However, the insights gained from the previous model studies on GPx may provide a solid basis not only for the development of more efficient GPx mimics but also for the design and synthesis of organoselenium compounds that could mimic the action of other selenoenzymes such as iodothyronine deiodinase and thioredoxin reductase for which successful synthetic mimics have not yet been developed. The reactivity of selenocysteine residues in selenoenzymes towards metal-containing compounds such as goldthioglucose may be utilized in the design and synthesis of metalbased drugs.

\section{Acknowledgement}

The work on selenoenzymes and selenocysteine derivatives in our laboratory is supported by the Department of Science and Technology (DST) and the Council for Scientific and Industrial Research (CSIR), New Delhi.

\section{References}

1. Berzelius J J 1818 Afhandl. Fys. Kemi Mineralog. 6 42
2. Schwarz K and Foltz C M 1957 J. Am. Chem. Soc. 793292

3. Andreesen J R and Ljungdahl L 1973 J. Bacteriol. 116867

4. Turner D C and Stadtman T C 1973 Arch. Biochem. Biophys. 154366

5. Flohé L, Günzler E A and Schock H H 1973 FEBS Lett. 32132

6. Rotruck J T, Pope A L, Ganther H E, Swanson A B, Hafeman D G and Hoekstra W G 1973 Science 179 588

7. Böck A 1994 Selenium proteins containing selenocysteine. In Encyclopedia of inorganic chemistry (ed.) R B King (Chichester: John Wiley) vol. 8, p. 3700

8. Flohé L, Andreesen J R, Brigelius-Flohé R, Maiorino $\mathrm{M}$ and Ursini $\mathrm{F} 2000$ IUBMB Life 49411

9. Boyington J C, Gladyshev V N, Khangulov S V, Stadtman T C and Sun P D 1997 Science 2751305

10. Wilting R, Schorling S, Persson B C and Böck A 1977 J. Mol. Biol. 266637

11. Garcin E, Vernede X, Hatchikian E C, Volbeda A Frey M and Fontecilla-Camps J C 1999 Structure 7 557

12. Pfeiffer M, Bingemann R and Klein A 1998 Eur. J. Biochem. 256447

13. Andreesen J R, Wagner M, Sonntag D, Kohlstock M, Harms C, Gursinsky T, Jäger J, Parther T, Kabisch U, Gräntzdörffer A, Pich A and Söhling B 1999 Biofactors 10263

14. Wagner M, Sonntag D, Grimm R, Pich A, Eckerskorn C, Söhling B and Andreesen J R 1999 Eur. J. Biochem. 26038 
15. Böck A, Forchhammer K, Heider J, Leinfelder W, Sawers G, Veprek B and Zinoni F 1991 Mol. Microbiol. 5515

16. Stadtman T C 1996 Annu. Rev. Biochem. 6583

17. Dobbek H, Gremer L, Meyer O and Huber R 1991 Proc. Natl. Acad. Sci. USA 968884

18. Behne D, Kyriakopoulos A, Meinhold H and Köhrle 1990 J. Biochem. Biophys. Res. Commun. 1731143

19. Arthur J R, Nicol F and Beckett G J 1990 Biochem. J. 272537

20. Davey J C, Becker K B, Schneider M J, Germain G L and Galton V A 1995 J. Biol. Chem. 27026786

21. Croteau W, Whittemore S K, Schneider M J and Germain D L 1995 J. Biol. Chem. 27016569

22. Lescure A, Gautheret D, Carbon P and Krol A 1999 J. Biol. Chem. 27438147

23. Tamura T and Stadtman T C 1996 Proc. Natl. Acad. Sci. USA 931006

24. Lee S R, Kim J R, Kwon K S, Yoon H W, Leveine R L, Ginsburg A and Rhee S G 1999 J. Biol. Chem. 2744722

25. Watabe S, Makino Y, Ogawa K, Hiroi T, Yamamoto Y and Takahashi S Y 1999 Eur. J. Biochem. 26474

26. Mustacich D and Powis G 2000 Biochem. J. 3461

27. Williams C H Jr, Arscott L D, Müller S, Lennon B W, Ludwig M L, Wang P-F, Veine D M, Becker K and Schirmer R H 2000 Eur. J. Biochem. 2676110

28. Motsenbocker M A and Tappel A L 1984 J. Nutr. 114279

29. Mills G C 1957 J. Biol. Chem. 229189

30. Ursini F, Maiorino M, Valente M, Ferri L and Gregolin C 1982 Biochim. Biophys. Acta 710197

31. Takahasi K, Avissar N, Whittin J and Cohen H 1987 Arch. Biochem. Biophys. 256677

32. Chu F-F, Doroshow J H and Esworthy R S $1993 \mathrm{~J}$. Biol. Chem. 2682571

33. Levander O A 1986 Selenium. Trace elements in human and animal nutrition (ed.) W Mertz (Orlando: Academic Press) vol. 2, p. 209

34. Levander O A 1987 Annu. Rev. Nutr. 7227

35. Néve J 1988 Biological functions of selenium. In Selenium in medicine and biology (eds) J Néve and A Favier (Berlin: W de Gruyter) p. 97

36. Burk R F (ed.) 1994 Selenium in biology and human health (New York: Springer-Verlag)

37. Ganther H E 1999 Carcinogenesis 201657

38. Köhrle J 1999 Biochimie 81527

39. Larsen P R and Berry M J 1995 Annu. Rev. Nutr. 15 323

40. Boschi-Muller S, Muller S, Van Dorsselaer A, Böck A and Branland G 1998 FEBS Lett. 439, 241

41. Baron C and Böck A 1995 tRNA: Structure, biosynthesis and function, pp 529-544

42. Low S C and Berry M J 1996 Trends Biochem. Sci. 21203

43. Glass R S, Singh W P, Jung W, Veres Z, Scholz T D and Stadtman T C 1993 Biochemistry 3212555

44. Böck A 2001 Encyclopedia Life Sci. 1-6

45. Forchhammer K and Böck A 1991 J. Biol. Chem. 2666324
46. Mizutani T, Kurata H, Yamada $\mathrm{K}$ and Totsuka $\mathrm{T}$ 1992 Biochem. J. 284827

47. Tormay P, Wilting R, Lootspeich F, Mehta P K, Chris-ten P and Böck A 1998 Eur. J. Biochem. 254 655

48. Forchhammer K, Bosemiller K and Böck A 1991 Biochimie 731481

49. Commans S S and Böck A 1999 FEMS Microbiol. Rev. 23335

50. Koide $\mathrm{T}$, Itoh $\mathrm{H}$, Otaka A, Yasui H, Kuroda M, Esaki N, Soda K and Fujii N 1993 Chem. Pharm. Bull. 41 502; Tamura T, Oikawa T, Ohtaka A, Fujii N, Esaki N and Soda K 1993 Anal. Biochem. 108151

51. (a) Theodoropoulas D, Schwartz I L and Walter R 1967 Biochemistry 6 3927; (b) Roy J, Gordon W, Schwartz I L and Walter R 1970 J. Org. Chem. 35 510

52. Mitsuru S, Kimiko H and Harushisa S 1997 Heterocycles 44319

53. Gieselman M D, Zhu Y, Zhou H, Galonic D and Vander Donk W A 2002 ChemBioChem. 3709

54. Gieselman M D, Xie L and Van der Donk W A 2001 Org. Lett. 31331

55. Hondal R J, Nilsson B L and Raines R T $2001 \mathrm{~J}$. Am. Chem. Soc. 123 5140; Quaderer R, Sewing A and Hilvert D 2001 Helv. Chim. Acta 841197

56. Review: Stadtman T C 1991 J. Biol. Chem. 266 16257

57. Review: Ursini F 1994 In Oxidative processes and antioxidants (ed.) R Paoletti (New York: Raven Press) p. 25

58. Maiorino M, Aumann K-D, Brigelius-Flohé, R Doria D, van den Heuvel J, McCarthy J, Rovery A, Ursini F and Flohé L 1995 Biol. Chem. HoppeSeyler 376651

59. Rocher C, Lalanne J-L and Chaudiére J 1992 Eur. J. Biochem. 205955

60. Maddipati K R and Marnett L J 1987 J. Biol. Chem. 26217398

61. Chu F-F, Doroshow J H and Esworthy R S $1993 \mathrm{~J}$. Biol. Chem. 2682571

62. Brigelius-Flohé R 1999 Free Radical Biol. Med. 27 951

63. Maiorino M, Gregolin C and Ursini F 1990 Methods Enzymol. 186448

64. Björnstedt M, Xue J, Huang W, Åkesson B and Holmgren A 1994 J. Biol. Chem. 26929382

65. Epp O, Ladenstein R and Wendel A 1983 Eur. J. Biochem. 13351

66. Ren W, Huang B, Akesson and Ladenstein R 1997 J. Mol. Biol. 268869

67. Schewe T 1995 Gen. Pharmacol. 261153

68. Parnham M J, Biederman J, Bittner C, Dereu N, Leyck S and Wetzig H 1989 Agents Actions 27306

69. Jacquemin P V, Christiaens L E, Renson M J, Evers M J and Dereu N 1992 Tetrahedron Lett. 333863

70. Reich H J and Jasperse C P 1987 J. Am. Chem. Soc. 1095549

71. Ostrovidov S, Franck P, Joseph D, Martarello L, Kirsch G, Belleville F, Nabet P and Dousset B 2000 J. Med. Chem. 431762 
72. Chaudiére J, Erdelmeier I, Moutet M and Yadam J-C 1998 Phosphorus, Sulphur, Silicon Relat. Elem. 136-138 467

73. Vessman K, Ekström M, Berglund M, Andersson C $\mathrm{M}$ and Engman L 1995 J. Org. Chem. 604461

74. Engman L, Stern D, Frisell H, Vessman K, Berglund M, Ek B and Andersson C-M 1995 Bioorg. Med. Chem. 31255

75. Engman L, Andersson C, Morgenstern R, Cotgreave I A, Andersson C-M and Hallberg A 1994 Tetrahedron $\mathbf{5 0} 2929$

76. Iwaoka M and Tomoda S 1994 J. Am. Chem. Soc. 1162557

77. Mugesh G, Panda A, Singh H B, Punekar N S and Butcher R J 2001 J. Am. Chem. Soc. 123839

78. Mugesh G, du Mont W-W and Sies H 2001 Chem. Rev. 101 2125; Mugesh G and Singh H B 2000 Chem. Soc. Rev. 29 347; Mugesh G and du Mont W-W 2001 Chem. Eur. J. 71365

79. Bell I M and Hilvert D 1993 Biochemistry 3213969

80. (a) Leonard J L and Visser T J 1986 Biochemistry of deiodination. In Thyroid hormone metabolism (ed.) G Hennemann (New York: Marcel Dekker) p. 189; (b) Berry M J, Banu L and Larsen P R 1991 Nature (London) 1991349 438; (c) Köhrle J 1996 Acta Med. Austriaca 23 17; (d) Leonard J L and Köhrle J 1996 Intracellular pathways of iodothyronine metabolism. In The thyroid (eds) L E Braverman and R D Utiger (Philadelphia: Lippincott-Raven) $\mathrm{p}$. 144; (e) St Germain D L and Galton V A 1997 Thyroid 7655

81. (a) Buxeraud J, Absil A C, Claude J, Raby C, Catanzano G and Beck C 1985 Eur. J. Med. Chem. 20 43; (b) Raby C, Lagorce J F, Jambut-Absil A C, Buxeraud J and Catanzano G 1990 Endocrinology 126 1683

82. Bassosi R, Niccolai N and Rossi C 1978 Biophys. Chem. 861

83. Berry M J, Kieffer J D, Harney J W and Larsen P R 1991 J. Biol. Chem. 26614155

84. (a) du Mont W-W, Mugesh G, Wismach C and Jones P G 1987 Angew. Chem., Int. Ed. 26 780; (b) Mugesh G, du Mont W-W, Wismach C and Jones P G 2002 ChemBioChem. 3440

85. Sandalova T, Zhong L, Lindqvist $\mathrm{Y}$, Holmgren A and Schneider G 2001 Proc. Natl. Acad. Sci. USA 989533

86. Freemerman A J, Gallegos A and Powis G 1999 Cancer Res. 594090

87. Oblong J E, Berggren M, Gasdaska P Y and Powis G 1994 J. Biol. Chem. 26911714

88. Arnér E S J and Holmgren A 2000 Eur. J. Biochem. 2676102

89. Waksman G, Krishna T S R, Sweet R M, Williams C H Jr and Kuriyan J 1994 J. Mol. Biol. 236800
90. (a) Nikitovic D and Holmgren A $1996 \mathrm{~J}$. Biol. Chem. 271 19180; (b) May J M, Mendiratta S, Hill K E and Burk R F 1997 J. Biol. Chem. 272 22607; (c) May J M, Cobb C E, Mendiratta S, Hill K E and Burk R F 1998 J. Biol. Chem. 273 23039; (d) Becker K, Savvidas S N, Keese M, Schirmer R H and Karplus P A 1998 Nat. Struct. Biol. 5267 (e) Gromer S, Schirmer R H and Becker K 1999 Redox Report 4 221; (f) Arteel GE, Briviba K and Sies H 1999 Chem. Res. Toxicol. 12 264; (g) Ganther H E 1999 Carcinogenisis 20 1657; (h) Becker K, Gromer S, Schirmer R H and Müller S 2000 Eur. J. Biochem. 267 6118; (i) Mustacich D and Powis G 2000 Biochem. J. 3461

91. Zhong L, Arnér E S J, Ljung J, Åslund F and Holmgren A 1998 J. Biol. Chem. 2738581

92. Zhong L, Arnér E S J and Holmgren A 2000 Proc. Natl. Acad. Sci. USA 975854

93. Williams C H Jr, Arscott L D, Müller S, Lennon B W, Ludwig M L, Wang P F, Veine D M, Becker K and Schirmer R H 2000 Eur. J. Biochem. 2676110

94. Björnstedt M, Xue J, Huang W, A Êkesson B and Holmgren A 1994 J. Biol. Chem. 26929382

95. Björnstedt M, Hamberg M, Kumar S, Xue J and Holmgren A 1995 J. Biol. Chem. 27011761

96. Zhong L, Arnér E S J and Holmgren A 2000 Proc. Natl. Acad. Sci. USA 975854

97. Gromer S, Urig and Becker K 2004 Med. Res. Rev. 2440

98. Schallreuter K U, Gleason F K and Wood J M 1990 Biochim. Biophys. Acta $\mathbf{1 0 5 4} 14$

99. Welsh S J, Williams R R, Birmingham A, Newman D J, Kirkpatrick D L and Powis G 2003 Mol. Cancer Ther. 2235

100. (a) Arscott L D, Gromer S, Schirmer R H, Becker K and Williams CH Jr 1997 Proc. Natl Acad. Sci. USA 94 3621; (b) Gromer S, Schirmer R H and Becker K 1997 FEBS Lett. 412 318; (c) Schallreuter K U, Gleason F K and Wood J M 1990 Biochim. Biophys. Acta $\mathbf{1 0 5 4} 14$

101. Sasada T, Nakamura H, Ueda S, Sato N, Kitaoka Y, Gon Y, Takabayashi A, Spyrou G, Holmgren A and Yodoi J 1999 Free Radic. Biol. Med. 27504

102. Mustachich D and Powis G 2000 Biochem. J. 3461

103. Gromer S, Schirmer R H and Becker K 1999 Redox Report 4221

104. Hofmann E R, Boyanapalli M, Lindner D J, Weihua X, Hassel B A, Jagus R, Gutierrez P L, Kalvakolanu D V and Hofman E R 1998 Mol. Cell. Biol. 18 6493

105. Zhong, L, Arnér E S, Ljung J, A Êslund F and Holmgren A 1998 J. Biol. Chem. 2738581

106. Gromer S, Arscott L D, Williams C H Jr, Schirmer R H and Becker K 1998 J. Biol. Chem. 27320096

107. Arnér E S 1999 Biofactors 10219 